\title{
Serum IgM against SARS-CoV-2 correlates with in-hospital mortality in severe/critical patients with COVID-19 in Wuhan, China
}

\author{
Xintian Liu ${ }^{1,3,{ }^{*}}$, Xuan Zheng ${ }^{2,}{ }^{,}$, Bo Liu ${ }^{1}$, Mingxiang $\mathrm{Wu}^{1}$, Zhenlu Zhang ${ }^{4}$, Gangcheng Zhang ${ }^{2}, \mathrm{Xi} \mathrm{Su}^{1}$ \\ ${ }^{1}$ Intensive Care Unit, Wuhan Asia General Hospital, Wuhan 430050, China \\ ${ }^{2}$ Cardiac Center, Wuhan Asia Heart Hospital, Wuhan 430022, China \\ ${ }^{3}$ Department of Cardiology, Wuhan Asia Heart Hospital, Wuhan 430022, China \\ ${ }^{4}$ Department of Clinical Laboratory, Wuhan Asia General Hospital, Wuhan 430050, China \\ *Equal contribution and Co-first authors
}

Correspondence to: Xi Su; email: suxi03@163.com

Keywords: severe acute respiratory syndrome coronavirus 2, COVID-19, intensive care, antibody, in-hospital mortality

Received: April 23, $2020 \quad$ Accepted: May 25, 2020

Published: July 6, 2020

Copyright: Liu et al. This is an open-access article distributed under the terms of the Creative Commons Attribution License (CC BY 3.0), which permits unrestricted use, distribution, and reproduction in any medium, provided the original author and source are credited.

\section{ABSTRACT}

Severe/critical patients with coronavirus disease 2019 (COVID-19) have become the central issue in the current global pandemic due to their high mortality rate. However, the relationship between antibody response and clinical outcomes has not been well described in this group. We conducted a single-center, retrospective, cohort study to investigate the relationship between serum immunoglobulin G (IgG) and IgM and clinical outcomes in severe/critical patients with COVID-19. Seventy-nine severe/critical patients with COVID-19 admitted in Wuhan Asia General Hospital in Wuhan, China during January 22, 2020 to March 6, 2020 were included. Serum antibodies were measured at day 25 (SD, 7) post illness onset. The median IgG titer was 113 (IQR 81-167) AU/ml, and IgM titer was 50 (IQR, 23-105) AU/ml. Patients whose IgM titer $\geq 50 \mathrm{AU} / \mathrm{ml}$ had higher in-hospital mortality ( $p=0.026)$. IgM titer $\geq 50 \mathrm{AU} / \mathrm{ml}$ was also correlated with higher incidences of Acute Respiratory Distress Syndrome (ARDS) and sepsis shock. Antibody remeasurements were performed in 42 patients, where IgM titer declined significantly in survivors $(p=0.031)$. Serum IgM titer changes according to the COVID-19 progression. The severe/critical patients with COVID-19 have a higher risk of clinical adverse events when IgM titer $\geq 50 \mathrm{AU} / \mathrm{ml}$. Further decreasing of IgM could imply a better outcome in severe/critical cases.

\section{INTRODUCTION}

Coronavirus disease 2019 (COVID-19) was first reported in Wuhan, China in December 2019. The highly contagious pneumonia caused by severe acute respiratory syndrome coronavirus 2 (SARS-CoV-2) soon spread all over the country, and has become a global pandemic [14]. Patients infected by SARS-CoV-2 might present from asymptomatic to critical illness with respiratory failure and multi-organ dysfunction, therefore, the disease was categorized into 4 types based on the disease state: mild, moderate, severe, and critical $[5,6]$. Severe/critical patients with COVID-19 contributed only $4 \sim 15 \%$ to overall infected population in different countries $[7,8]$, however, attentions have been paid to them not only because of their rapid progression in disease, but also due to the greater difficulties in treatment and higher mortality rate $[7,9,10]$.

Antibody response in human might be activated at early stage of infectious disease, then be kept stable for a long time. Specific serum immunoglobulin $\mathrm{G}(\mathrm{IgG})$ and $\operatorname{IgM}$ against SARS-CoV or Middle East Respiratory Syndrome-coronavirus (MERS-CoV) became detectable in patients as early as 11-15 days post illness onset $[11,12]$. Similar changes were observed in patients with COVID-19 as IgM and IgG could be detected on 5-14 days after symptom onset [13]. 
Additionally, the titers of $\operatorname{IgM}$ and $\operatorname{IgG}$ were significantly correlated with viral load in patients infected by SARS-CoV-2 in a recent finding [14], which promoted the hypothesis that specific antibody against virus might be associated with disease progression in COVID-19. However, reports on clinical profiles of antibody response in severe/critical patients with COVID-19 are scarce.

Hereby, we investigated the serum titers of specific antibodies, $\operatorname{IgG}$ and $\operatorname{IgM}$, in severe/critical patients with COVID-19 to explore the association between serum antibody titers and the clinical adverse events in those patients.

\section{RESULTS}

\section{Characteristics of the patients}

A total of 105 severe/critical patients with COVID-19 admitted to Wuhan Asia General Hospital from 2020.01.22 to 2020.03.06 were enrolled, Of which, 23 were excluded due to the incomplete data, 3 due to negative in antibody measurements. Therefore, 79 patients were reviewed in final analysis, whose mean age was 63 (SD 13) years. Seven (9\%) patients were smokers, and comorbidities included $5(6 \%)$ chronic obstructive pulmonary disease (COPD), 31 (39\%) hypertension, $13(16 \%)$ diabetes, $6(8 \%)$ coronary artery disease (CAD), and $2(3 \%)$ chronic kidney disease (CKD). The most common symptoms were fever in 64 (81\%) patients, cough in 57 (72\%), dyspnea in 49 $(62 \%)$, and fatigue in $44(56 \%)$. The average time from illness onset to admission was 12 days (SD, 6). All patients had significantly change on lung computerized tomography (CT).

\section{Antibody response and in-hospital mortality}

Eleven (14\%) patients died during hospitalization, who were older than survivors (73 [SD 9] vs 61 [SD 2], $\quad P=0.002)$. There were $16 \quad(20 \%)$ Acute Respiratory Disease Syndrome (ARDS) and 11 (14\%) septic shock happening during hospitalization. Patients had their measurements of serum antibody against SRAS-CoV-2 on day 13 (SD, 7) post admission when tests were available, which was 25 (SD, 7) days after illness onset. The median IgG titer was 113 (IQR, 81-167) AU/ml, and that of IgM was 50 (IQR, 23-105) AU/ml. The difference of IgG titer between survivors and non-survivors was trivial (113 [IQR, 81-167] vs 135 [IQR, 82-158] AU/ml, $P=0.887$, however, IgM titer was significantly increased in non-survivor when comparing with survivors (106 [IQR, 50-128] vs 48 [IQR, 22-84] $\mathrm{AU} / \mathrm{ml}, P=0.049$ ) (Figure 1). Forty-two patients had antibody remeasurements $5(\mathrm{SD}, 3)$ days later. The median IgG titer was 150 (IQR 88-179) $\mathrm{AU} / \mathrm{ml}$ at $2^{\text {nd }}$ time, and that of IgM was 66 (IQR 32-133) AU/ml. IgG titer remained stable during two measurements in both survivors and non-survivors. Change of IgM titer in survivors showed a significantly decreasing (4 [IQR -14-0], $P=0.031$ ), but that in non-survivors didn't show statistical difference (3 [IQR -19-29], $P=0.779$ ) (Figure 2).

\section{Serum IgM and clinical outcomes}

We further divided patients into two groups using median serum IgM titer as cutoff. Clinical characteristics, such as age, gender, comorbidity, symptoms, time intervals, and vital signs at admission, were similar between the two groups (Table 1). Disease severity was quite different, as a higher incidence of critical cases was seen in the high IgM group $(p=0.006)$ (Table 1). Laboratory measurements presented differently between groups (Table 2). All patients received basic therapy as well as specific treatment based on their disease progression in hospital. More Intensive medical supports were applied in patients whose IgM titer $\geq 50 \mathrm{AU} / \mathrm{ml}$ (Table 3).

\section{DISCUSSION}

In this retrospective cohort study, IgG and IgM against SARS-CoV-2 in severe/critical patients with COVID-19 were profiled, and relationship between antibody titers

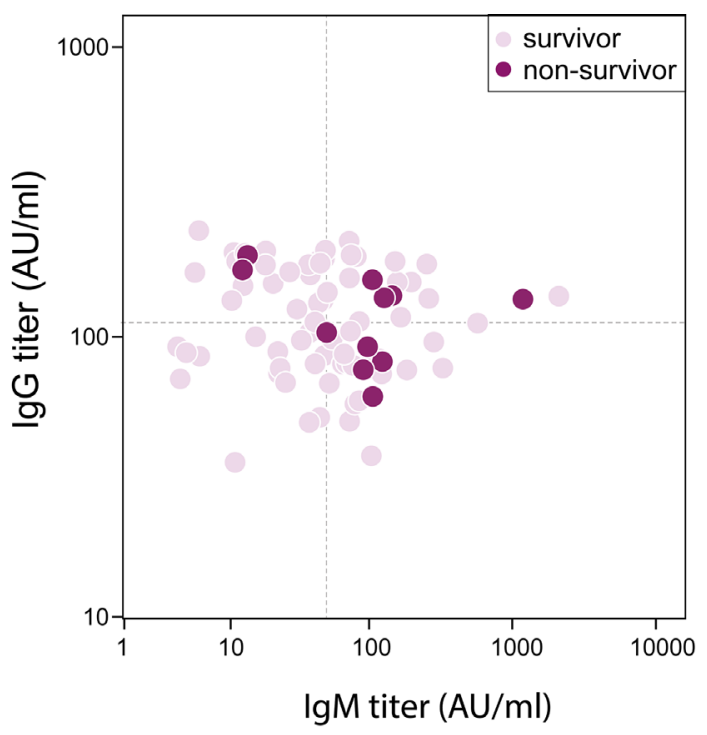

Figure 1 Correlation between Antibody titer and inhospital mortality in severe/critical patients with COVID-19. Dash lines represent median value as cutoff in IgG (113 AU/ml) and IgM (50 AU/ml) respectively. 
and outcomes was also assessed. Specifically, compared with survivors, IgM titer increased in non-survivors while IgG remained unchanged when measurements were performed on 25 (SD, 7) days after illness onset. IgM further decreased in survivors when taking remeasurement 5 (SD, 3) days later. Accompanied by significantly changes in laboratory measurements, more critical cases were seen in patients with $\operatorname{IgM}$ titer $\geq 50$ AU $/ \mathrm{ml}$. Higher frequencies of applying corticosteroids and mechanical ventilation were also observed in patients with $\mathrm{IgM}$ titer $\geq 50 \mathrm{AU} / \mathrm{ml}$.

Pneumonia caused by SARS-CoV-2, which was later known as COVID-19, occurred in Wuhan, China in December 2019 [1, 15]. The estimated reproductive number rose from 2.2 to 3.28 [14], and overall mortality rate was around $2-4 \%$ [16-18], which might be still increasing as more than one million patients have been confirmed infection, and new deaths are reported globally. Nearly $80 \%$ of patients with COVID19 might present only mild or moderate symptoms, such as fever, and cough [8,19], however, more than $50 \%$ death could be seen in severe/critical cases [7, 20]. Similar to previous studies, non-survivors in our study were older than survivors. There were no differences in comorbidities between survivors and non-survivors in our study, probably due to the variation in the spectrum of underlying diseases. In-hospital mortality (14\%) in our study was lower than that in other reports, nonetheless, at least 5 folds higher mortality in severe/critical patients, again, strengthened that great efforts should be paid on this group.

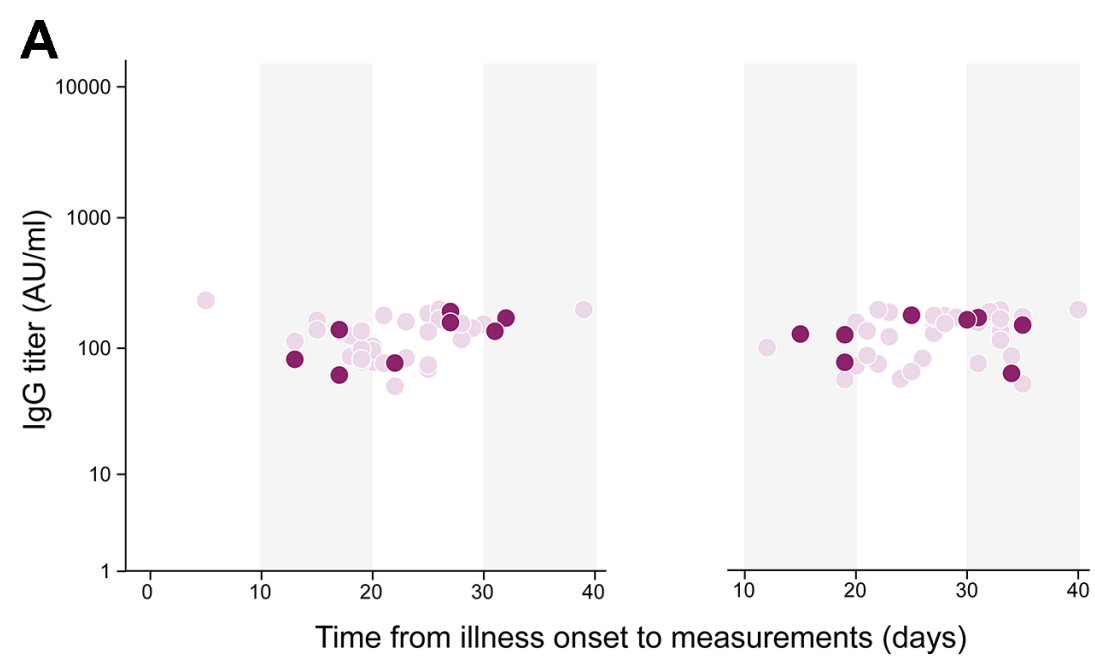

survivor
non-survivor

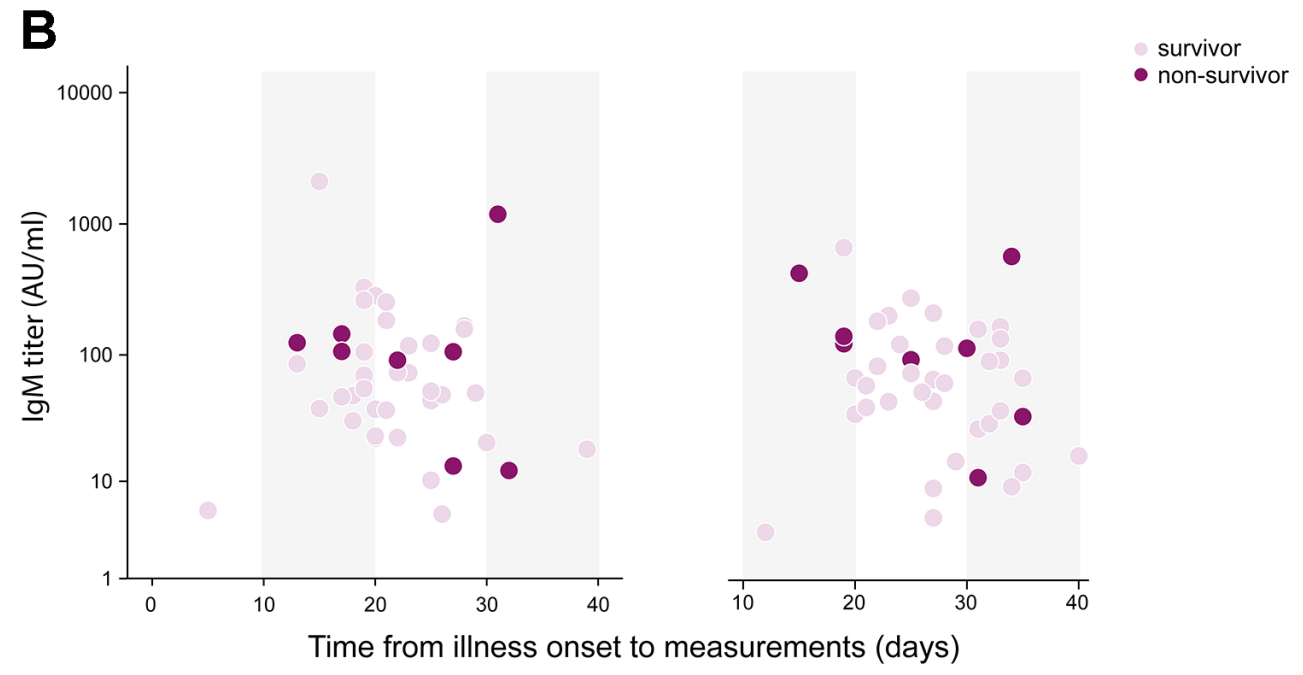

Figure 2. Temporal profile of serum antibodies in severe/critical patients with COVID-19. 42 patients had two antibody measurements on day 25 (SD, 7) and on day 27 (SD, 6) post illness onset respectively. (A) IgG titer remained stable during two measurements in both survivors and non-survivors. (B) Change of IgM titer in survivors showed a significantly decreasing $(-4$ [IQR $-14-0], P=0.031)$, but that in non-survivors didn't show statistical difference (3 [IQR -19-29], $\mathrm{P}=0.779$ ). 
Table 1. Clinical characteristics of patients with different IgM titers.

\begin{tabular}{|c|c|c|c|}
\hline & $\begin{array}{c}\text { IgM }<50 \mathrm{50} \mathrm{AU} / \mathrm{ml} \\
(\mathbf{n}=\mathbf{3 9})\end{array}$ & $\begin{array}{c}\operatorname{IgM} \geq 50 \mathrm{AU} / \mathrm{ml} \\
(\mathrm{n}=40)\end{array}$ & $P$ \\
\hline Age, years & $64 \pm 11$ & $61 \pm 14$ & 0.315 \\
\hline Men & $25(64)$ & $25(63)$ & 0.883 \\
\hline Current smoker & $5(13)$ & $2(5)$ & 0.221 \\
\hline \multicolumn{4}{|l|}{ Comorbidity } \\
\hline Chronic obstructive lung disease & $3(8)$ & $2(5)$ & 0.623 \\
\hline Hypertension & $17(44)$ & $14(35)$ & 0.434 \\
\hline Diabetes & $7(18)$ & $6(15)$ & 0.724 \\
\hline Coronary heart disease & $4(10)$ & $2(5)$ & 0.378 \\
\hline Chronic kidney disease & $0(0)$ & $2(5)$ & 0.494 \\
\hline \multicolumn{4}{|l|}{ Symptoms } \\
\hline Fever & $30(77)$ & $34(85)$ & 0.360 \\
\hline Cough & $28(72)$ & $29(73)$ & 0.944 \\
\hline Sputum & $15(38)$ & $11(28)$ & 0.300 \\
\hline Myalgia & $1(3)$ & $5(13)$ & 0.201 \\
\hline Fatigue & $22(56)$ & $22(55)$ & 0.900 \\
\hline Diarrhoea & $6(15)$ & $6(15)$ & 0.962 \\
\hline Dyspnea & $25(64)$ & $24(60)$ & 0.707 \\
\hline $\begin{array}{l}\text { Time from illness onset to } \\
\text { hospital admission, days }\end{array}$ & $10(7-14)$ & $12(10-14)$ & 0.172 \\
\hline $\begin{array}{l}\text { Time from illness onset to } \\
\text { first antibody detection, days }\end{array}$ & $26(21-31)$ & $23(19-29)$ & 0.183 \\
\hline $\begin{array}{l}\text { Time from hospital admission to } \\
\text { first antibody detection, days }\end{array}$ & $13(9-21)$ & $11(7-15)$ & 0.153 \\
\hline \multicolumn{4}{|l|}{ Vital signs on admission } \\
\hline Temperature, ${ }^{\circ} \mathrm{C}$ & $36.9 \pm 0.6$ & $36.9 \pm 0.9$ & 0.774 \\
\hline Systolic pressure, $\mathrm{mmHg}$ & $129 \pm 18$ & $128 \pm 18$ & 0.857 \\
\hline Diastolic pressure, $\mathrm{mmHg}$ & $78 \pm 12$ & $76 \pm 9$ & 0.461 \\
\hline Heart rate, beats $/ \mathrm{min}$ & $91 \pm 18$ & $87 \pm 14$ & 0.275 \\
\hline Disease severity state & & & 0.003 \\
\hline Severe & $36(92)$ & $26(65)$ & \\
\hline Critical & $3(8)$ & $14(35)$ & \\
\hline
\end{tabular}

Data are mean $\pm \mathrm{SD}$, median (IQR) or $\mathrm{n}(\%)$. IgM = Immunoglobulin $\mathrm{M}$.

Table 2. Laboratory measurements of patients with different IgM titers.

\begin{tabular}{lccc}
\hline & $\begin{array}{c}\text { IgM }<\mathbf{5 0} \mathbf{~ A U} / \mathbf{m l} \\
(\mathbf{n = 3 9 )}\end{array}$ & $\begin{array}{c}\text { IgM } \geq \mathbf{5 0} \mathbf{~ A U} / \mathbf{m l} \\
(\mathbf{n = 4 0})\end{array}$ & $\boldsymbol{P}$ \\
\hline Arterial blood gas analysis & & & \\
$\mathrm{PH}$ & $7.38 \pm 0.06$ & $7.40 \pm 0.05$ & 0.136 \\
$\mathrm{PaCO} 2, \mathrm{mmHg}$ & $44 \pm 7$ & $42 \pm 8$ & 0.277 \\
$\mathrm{PaO} 2, \mathrm{mmHg}$ & $59 \pm 6$ & $56 \pm 7$ & 0.044 \\
$\mathrm{SaO} 2, \%$ & $91 \pm 4$ & $89 \pm 4$ & 0.039 \\
White blood cell count, $\times 10^{9} / \mathrm{L}$ & $6.9 \pm 3.0$ & $7.1 \pm 2.8$ & 0.777 \\
Neutrophil count, $\times 10^{9} / \mathrm{L}$ & $5.5 \pm 2.9$ & $5.8 \pm 2.9$ & 0.608 \\
Lymphocyte count, $\times 10^{9} / \mathrm{L}$ & $0.9 \pm 0.4$ & $0.9 \pm 1.0$ & 0.800 \\
Haemoglobin, $\mathrm{g} / \mathrm{L}$ & $126 \pm 15$ & $126 \pm 19$ & 0.812 \\
Platelet count, $\times 10^{9} / \mathrm{L}$ & $249 \pm 118$ & $228 \pm 87$ & 0.369 \\
ALT, U/L & $24(18-44)$ & $39(16-63)$ & 0.161 \\
Albumin, $\mathrm{g} / \mathrm{L}$ & $34 \pm 4$ & $32 \pm 5$ & 0.010 \\
Creatinine, $\mu$ mol/L & $86 \pm 26$ & $83 \pm 38$ & 0.730 \\
Prothrombin time, $\mathrm{s}$ & $12.0 \pm 0.8$ & $12.4 \pm 1.2$ & 0.085
\end{tabular}


Fibrinogen, g/L

D-dimer, mg/L

Cardiac troponin $\mathrm{T}, \mathrm{pg} / \mathrm{ml}$

NT-proBNP, pg/ml

C-reactive protein, $\mathrm{mg} / \mathrm{L}$

IL-6, pg/mL

TNF- $\alpha, p g / m L$
$5.0 \pm 1.9$
$5(0.44-2.59)$
$10(6-18)$
$80(59-252)$
$40(12-107)$
$17(6-70)$
$11(8-17)$

$5.2 \pm 1.7$
$1.81(0.77-9.06)$
$12(8-20)$
$264(73-590)$
$69(27-126)$
$42(12-119)$
$9(5-12)$

0.623

0.020

0.666

0.031

0.119

0.141

0.111

Data are mean \pm SD or median (IQR). IgM = Immunoglobulin M. PH = Pondus Hydrogenii. PaCO2 = partial pressure of carbon dioxide. $\mathrm{PaO} 2$ = partial pressure of oxygen. $\mathrm{SaO} 2=$ arterial oxygen saturation. $\mathrm{ALT}=$ alanine aminotransferase. $\mathrm{NT}-\mathrm{proBNP}=$ $\mathrm{N}$-terminal pro-brain natriuretic peptide. IL-6=interleukin-6. TNF- $\alpha=$ tumor necrosis factor- $\alpha$.

Table 3. Treatments and outcomes of patients with different IgM titers

\begin{tabular}{|c|c|c|c|}
\hline & $\begin{array}{c}\text { IgM }<50 \mathrm{AU} / \mathrm{ml} \\
(\mathrm{n}=39)\end{array}$ & $\begin{array}{c}\text { IgM } \geq 50 \mathrm{AU} / \mathrm{ml} \\
(\mathrm{n}=40)\end{array}$ & $\boldsymbol{P}$ \\
\hline \multicolumn{4}{|l|}{ Drugs } \\
\hline Antiviral treatment & $36(92)$ & $38(95)$ & 0.675 \\
\hline Antibiotics & $36(92)$ & $39(98)$ & 0.359 \\
\hline Corticosteroids & $16(41)$ & $32(80)$ & $<0.001$ \\
\hline Chinese traditional medicine & $39(100)$ & $39(98)$ & 1.000 \\
\hline Non-invasive & $3(8)$ & $13(33)$ & 0.006 \\
\hline Invasive & $0(0)$ & $9(23)$ & 0.002 \\
\hline Other advanced supportive therapy & $1(3)$ & $4(10)$ & 0.175 \\
\hline IABP & $0(0)$ & $1(3)$ & 0.320 \\
\hline CRRT & $1(3)$ & $4(10)$ & 0.175 \\
\hline Septic shock & $2(5)$ & $9(23)$ & 0.026 \\
\hline In-hospital mortality & $2(5)$ & $9(23)$ & 0.026 \\
\hline Hospital length of stay, days & $29(21-30)$ & $29(19-31)$ & 0.941 \\
\hline
\end{tabular}

Data are median (IQR) or $\mathrm{n}(\%)$. IgM = Immunoglobulin $\mathrm{M}$. IABP = intra-aortic balloon pump. CRRT = continuous renal replacement therapy. ECMO = extracorporeal membrane oxygenation. ARDS = Acute Respiratory Distress Syndrome.

Serum IgM is the first protein producing in human in response to the exposure to an antigen, such as bacterial, virus, and others. IgM titer could increase in hours to respond antigen attack followed by degradation in weeks. Being a secondly important antibody, IgG would be activated in a moderate but long-lasting way. It might slowly rise in weeks after recognizing antigen, and reach a plateau for years. Guo et al. examined 208 samples from confirmed and suspected patients with COVID-19. Specific antibodies could be positive as early as day 1 after illness onset. For most patients, IgM appeared at day 5 and became stable at days 15-21 after increasing at day 8. IgG showed same change as IgM at acute phase but continued its rising until plateau at day 21 [13]. Our patients had their antibody measurement on day 25 (SD7), and repeated on day 27 (SD6). Despite of the stable levels in IgG and IgM, our measurements were performed later than other studies. We believed the results were still robust because the measurements were performed at the time when both $\operatorname{IgG}$ and $\operatorname{IgM}$ were in plateau according to previous studies [21], and the $\operatorname{IgG}$ and $\operatorname{IgM}$ titers remained high and detectable in our study. Moreover, we observed IgM might decrease on day 27 (SD 6) if patients recovered. As Mo et al mentioned in their study, IgM against SARS-CoV declined much earlier than IgG [22]. The decreasing of IgM against SARS-CoV-2 in survivors from our study might be a natural change of IgM in COVID-19. On the other hand, To et al. investigated the correlation between serum antibody response and viral load. They found IgG and IgM titers were highly correlated with viral load in patients with COVID-19, which might explain why our patients had a recover in their illness in consistent with IgM decreasing [14]. One thing might be noticed, there were 10 patients having negative molecular tests in our study, even though they presented critical illness. Similar findings were seen in the 
study by Zhang et al. They observed positive rate in molecular tests might be reducing as time from illness onset prolonged, while IgG and IgM titers were stable in all patients [23]. The reasons for this were discussed before: viral RNA might vary from oral swabs to anal swabs; mismatch in the detection probes; fluctuation in viral load unparalleled with illness progression [24, 25].

Efforts have been made to distinguish patients at high risk of mortality. Studies proposed age, comorbidities, CT imaging, and other parameters, which showed differences in survivors and non-survivors [26, 27], to predict risks in patients with COVID-19. Nonetheless, we didn't find many differences between survivors and non-survivors in our study. Severe and critical illness in our patients might eliminate the influence by other factors. On the contrary, our study supported the clinical application of serum IgM in severe/critical patients with COVID-19 for risk stratification. Significantly higher mortality rate was seen in patients when their serum IgM was higher than $50 \mathrm{AU} / \mathrm{ml}$. Additionally, serial changes in IgM titer also helped to follow the disease progression in patients with poor prognosis.

Our study showed that advanced supportive treatment together with combination therapy were more applied in patients with high mortality. The high levels of IgM in our patients might indicate a disease worsening despite of the treatment. Treatment strategy was proposed based on the disease stage, however, no evidence had been shown to be most specific to COVID-19 [28]. Patients might show different response to corticosteroids [29, 30]. Although patients admitted into ICU required more medical treatments, the effect of advanced support seemed to be controversial in critical patients [31,32]. The ideally strategy to treat viral pneumonia has always been remove the virus as soon as possible. The antivirus effect by Remdesivir in patient and cells might bring hope in further treatment [33, 34].

There were some limitations in our studies. Firstly, there were only 79 patients included in our study. The small size of study population might bring bias to data distribution. Further study should involve more patients to investigate the clinical profile of antibody response. Secondly, our antibody measurements started on 25 days post illness onset. The late measurements missed early change of antibody in patients. New studies might consider a broader interval to cover more changes. Thirdly, we focused on in-hospital mortality for severe/critical patients. However, there were reports that patients might have disease progression after discharge [24]. We might follow-up our patients for a longer time to see the relationship between antibody titer and their prognosis.

\section{CONCLUSIONS}

Our study demonstrated the dynamic change of antibody titer in consistent with disease progression. A higher risk of in-hospital mortality was seen in severe/critical patients of COVID-19 when their IgM titer $\geq 50 \mathrm{AU} / \mathrm{ml}$. Further decreasing of IgM could imply a better prognosis in severe/critical patients. Serial measurements of serum antibody provide comprehensive evaluation to the process of COVID-19.

\section{MATERIALS AND METHODS}

\section{Study design and patients}

A retrospective cohort study was conducted in Wuhan Asia General Hospital, Wuhan, China to investigate the clinical profile of serum antibodies against SARS-CoV2 in severe/critical patients with COVID-19. The study protocol was reviewed and approved by the Ethics Committee of Wuhan Asia General hospital with a waiver of informed consent (WAGHMEC-KY2020007). Personal information of patients was reidentified before analysis.

A total of 105 severe/critical patients with COVID-19 admitted in Wuhan Asia General hospital between 2020.01.22 and 2020.03.06 were reviewed. COVID-19 was diagnosed according to the Chinese management guideline for COVID-19 (version 7.0) [6]. New laboratory criteria of COVID-19-specific IgM and IgG positive, and 4 folds increasing of COVID-19-specific IgG titer in recovery period were added in guideline 7.0 [6]. Severe patients with COVID-19 met any of the followings: (1) Shortness of breath, respiratory rate $\geq 30$ times per minute; (2) Oxygen saturation $\leq 93 \%$ at rest; (3) Alveolar oxygen partial pressure/fraction of inspiration $\mathrm{O} 2 \quad(\mathrm{PaO} 2 / \mathrm{FiO} 2) \leq 300 \mathrm{mmHg}$ $(1 \mathrm{mmHg}=0.133 \mathrm{kPa})$. Critical patients had any of the conditions: (1) Respiratory failure requiring mechanical ventilation; (2) Shock; (3) Patients combined with other organ failure needed intensive care unit (ICU) monitoring and treatment [6]. Fever was defined as axillary temperature greater than $37 \cdot 3^{\circ} \mathrm{C}$.

\section{Data collection}

Clinical data including age, gender, vital signs, comorbidity were collected from medical records at admission. Laboratory biomarkers such as $\operatorname{IgG}$ titer, IgM titer, blood gas analysis, white blood cell count (WBC), alanine aminotransferase (ALT), D-dimer, and N-terminal prohormone of brain natriuretic peptide (NT-proBNP) were also collected. Specifically, serum IgG and IgM that against SARS-CoV-2 nucleocapsid protein and envelop protein were measured by 
chemiluminescence immunoassay (CLIA) in automatic system when it was available on February 18, 2020. Antibody titer $>10 \mathrm{AU} / \mathrm{ml}$ was taken as positive. All blood tests were analyzed in fresh blood and determined by standard quantitative assay techniques in our Department of Clinical Laboratory according to the manufacturer's protocol.

\section{Outcomes}

The primary outcome was in-hospital mortality. The secondary outcomes included ARDS related to SARSCoV-2 infection and sepsis shock secondary to COVID-19. ARDS was diagnosed according to the Berlin Definition [35]. Sepsis shock was defined according to the 2016 Third International Consensus Definition [36].

\section{Statistical analysis}

Data are shown as number for categorical data, and mean \pm standard deviation or median with interquartile range (IQR) as appropriate for continuous data. Data were compared with student $t$ test or Wilcoxon signed-rank test for continuous variables depending on the normality of their distributions and with the $\chi^{2}$ test for categorical variables. Comparison between the first and second antibody titer is performed by paired samples Wilcoxon test. A two-side $P<0.05$ was considered as statistic significant. All statistical analyses were performed with SPSS 23.0 (IBM Corp, Armonk, NY).

\section{Abbreviations}

ALT: alanine aminotransferase; ARDS: acute respiratory distress syndrome; CAD: coronary artery disease; CKD: chronic kidney disease; COPD: chronic obstructive pulmonary disease; COVID-19: coronavirus disease 2019; CLIA: chemiluminescence immunoassay; ICU: intensive care unit; IgG: immunoglobulin G; IQR: interquartile range; MERS-CoV: Middle East Respiratory Syndrome-coronavirus; NT-proBNP: Nterminal prohormone of brain natriuretic peptide; $\mathrm{PaO}$ 2/FiO2: Alveolar oxygen partial pressure/fraction of inspiration O2; SARS-CoV-2: severe acute respiratory syndrome coronavirus 2; SD: standard deviation; WBC: white blood cell count.

\section{AUTHOR CONTRIBUTIONS}

Xintian Liu and Xuan Zheng designed the study. Bo Liu and Mingxiang $\mathrm{Wu}$ collected the epidemiological and clinical data. Zhenlu Zhang provided laboratory measurements and collected the data. Xintian Liu, Xuan Zheng and $\mathrm{Xi} \mathrm{Su}$ summarized all data. Gangcheng
Zhang, Xi Su, Xintian Liu and Xuan Zheng drafted the manuscript. All the authors proved the final version of this manuscript.

\section{ACKNOWLEDGMENTS}

We thank all patients and their families involved in the study. We would like to appreciate all clinicians coming from all over the country and helping to fight against the disease. We would like to thank all generous help from other counties when Wuhan, China was in COVID-19 outbreak.

\section{CONFLICTS OF INTEREST}

The authors declare no conflicts of interest.

\section{FUNDING}

This study was supported by Wuhan young and middleaged medical backbone talents (the sixth batch, no. 116, family planning tong [2018] to Dr. Liu, and the fifth batch, no. 72, family planning tong [2017] to Dr. Zheng).

\section{REFERENCES}

1. Zhu N, Zhang D, Wang W, Li X, Yang B, Song J, Zhao X, Huang B, Shi W, Lu R, Niu P, Zhan F, Ma X, et al, and China Novel Coronavirus Investigating and Research Team. A novel coronavirus from patients with pneumonia in China, 2019. N Engl J Med. 2020; 382:727-33.

https://doi.org/10.1056/NEJMoa2001017

PMID:31978945

2. Huang $C$, Wang $Y$, Li $X$, Ren L, Zhao J, Hu Y, Zhang L, Fan G, Xu J, Gu X, Cheng Z, Yu T, Xia J, et al. Clinical features of patients infected with 2019 novel coronavirus in wuhan, China. Lancet. 2020; 395:497-506. https://doi.org/10.1016/S0140-6736(20)30183-5 PMID:31986264

3. Sohrabi C, Alsafi Z, O'Neill N, Khan M, Kerwan A, AlJabir A, losifidis C, Agha R. World health organization declares global emergency: a review of the 2019 novel coronavirus (COVID-19). Int J Surg. 2020; 76:71-76.

https://doi.org/10.1016/j.ijsu.2020.02.034 PMID:32112977

4. Cucinotta D, Vanelli M. WHO declares COVID-19 a pandemic. Acta Biomed. 2020; 91:157-60. https://doi.org/10.23750/abm.v91i1.9397 PMID: $\underline{2191675}$

5. Li T. Diagnosis and clinical management of severe acute respiratory syndrome coronavirus 2 (SARS-CoV2) infection: an operational recommendation of peking 
union medical college hospital (V2.0). Emerg Microbes Infect. 2020; 9:582-85.

https://doi.org/10.1080/22221751.2020.1735265

PMID:32172669

6. Commission CNH. Chinese Clinical Guidance for COVID19 Pneumonia Diagnosis and Treatment (7th edition). 2020.

7. Yang $X, Y u Y, X u$ J, Shu H, Xia J, Liu H, Wu Y, Zhang L, Yu $Z$, Fang $M, Y u T$, Wang $Y$, Pan $S$, et al. Clinical course and outcomes of critically ill patients with SARS-CoV-2 pneumonia in wuhan, China: a single-centered, retrospective, observational study. Lancet Respir Med. 2020; 8:475-81.

https://doi.org/10.1016/S2213-2600(20)30079-5 PMID:32105632

8. Wu Z, McGoogan JM. Characteristics of and Important Lessons From the Coronavirus Disease 2019 (COVID19) Outbreak in China: Summary of a Report of 72314 Cases From the Chinese Center for Disease Control and Prevention. JAMA. 2020. [Epub ahead of print].

https://doi.org/10.1001/jama.2020.2648 PMID:32091533

9. Zhou F, Yu T, Du R, Fan G, Liu Y, Liu Z, Xiang J, Wang Y, Song B, Gu X, Guan L, Wei Y, Li H, et al. Clinical course and risk factors for mortality of adult inpatients with COVID-19 in wuhan, China: a retrospective cohort study. Lancet. 2020; 395:1054-62.

https://doi.org/10.1016/S0140-6736(20)30566-3 PMID:32171076

10. Li K, Wu J, Wu F, Guo D, Chen L, Fang Z, Li C. The clinical and chest CT features associated with severe and critical COVID-19 pneumonia. Invest Radiol. 2020; 55:327-31.

https://doi.org/10.1097/RLI.0000000000000672 PMID:32118615

11. Mo HY, Xu J, Ren XL, Zeng GQ, Tan YX, Chen RC, ChanYeung $M$, Zhong NS. Evaluation by indirect immunofluorescent assay and enzyme linked immunosorbent assay of the dynamic changes of serum antibody responses against severe acute respiratory syndrome coronavirus. Chin Med J (Engl). 2005; 118:446-50.

PMID:15788124

12. Wang $\mathrm{WL}$, Wang $\mathrm{HJ}$, Deng $\mathrm{Y}$, Song $\mathrm{T}$, Lan JM, Wu GZ, Ke CW, Tan WJ. Serological study of an imported case of middle east respiratory syndrome and his close contacts in China, 2015. Biomed Environ Sci. 2016; 29:219-23.

https://doi.org/10.3967/bes2016.027 PMID:27109133

13. Guo L, Ren L, Yang S, Xiao M, Chang D, Yang F, Dela Cruz CS, Wang Y, Wu C, Xiao Y, Zhang L, Han L, Dang S, et al. Profiling Early Humoral Response to Diagnose Novel Coronavirus Disease (COVID-19). Clin Infect Dis. 2020. [Epub ahead of print]. https://doi.org/10.1093/cid/ciaa310 PMID:32198501

14. To KK, Tsang OT, Leung WS, Tam AR, Wu TC, Lung DC, Yip CC, Cai JP, Chan JM, Chik TS, Lau DP, Choi CY, Chen $\mathrm{LL}$, et al. Temporal profiles of viral load in posterior oropharyngeal saliva samples and serum antibody responses during infection by SARS-CoV-2: an observational cohort study. Lancet Infect Dis. 2020; 20:565-74.

https://doi.org/10.1016/S1473-3099(20)30196-1 PMID:32213337

15. Zhou $P$, Yang $X L$, Wang $X G$, Hu B, Zhang L, Zhang $W, S i$ $H R$, Zhu Y, Li B, Huang CL, Chen HD, Chen J, Luo Y, et al. A pneumonia outbreak associated with a new coronavirus of probable bat origin. Nature. 2020; 579:270-73.

https://doi.org/10.1038/s41586-020-2012-7 PMID:32015507

16. Porcheddu R, Serra C, Kelvin D, Kelvin N, Rubino S. Similarity in case fatality rates (CFR) of COVID-19/SARSCOV-2 in Italy and China. J Infect Dev Ctries. 2020; 14:125-28.

https://doi.org/10.3855/iidc.12600

PMID:32146445

17. $X u X W, W u X X$, Jiang $X G$, Xu KJ, Ying $L, M a C L, L i S B$, Wang HY, Zhang S, Gao HN, Sheng JF, Cai HL, Qiu YQ, Li $\amalg$. Clinical findings in a group of patients infected with the 2019 novel coronavirus (SARS-cov-2) outside of wuhan, China: retrospective case series. BMJ. 2020; 368:m606. https://doi.org/10.1136/bmj.m606 PMID:32075786

18. Young BE, Ong SW, Kalimuddin S, Low JG, Tan SY, Loh J, Ng OT, Marimuthu K, Ang LW, Mak TM, Lau SK, Anderson DE, Chan KS, et al, and Singapore 2019 Novel Coronavirus Outbreak Research Team. Epidemiologic features and clinical course of patients infected with SARS-CoV-2 in Singapore. JAMA. 2020; 323:1488-94. https://doi.org/10.1001/jama.2020.3204 PMID:32125362

19. Ge H, Wang X, Yuan X, Xiao G, Wang C, Deng T, Yuan $Q$, Xiao $X$. The epidemiology and clinical information about COVID-19. Eur J Clin Microbiol Infect Dis. 2020; 39:1011-1019. https://doi.org/10.1007/s10096-020-03874-z PMID:32291542

20. Bhatraju PK, Ghassemieh BJ, Nichols M, Kim R, Jerome KR, Nalla AK, Greninger AL, Pipavath S, Wurfel MM, Evans L, Kritek PA, West TE, Luks A, et al. Covid-19 in critically ill patients in the seattle region - case series. $\mathrm{N}$ Engl J Med. 2020; 382:2012-22. 
https://doi.org/10.1056/NEJMoa2004500

PMID: $\underline{2227758}$

21. Xiao DAT, Gao DC, Zhang DS. Profile of Specific Antibodies to SARS-CoV-2: The First Report. J Infect. 2020; 81:147-78.

https://doi.org/10.1016/i.jinf.2020.03.012

22. Mo H, Zeng G, Ren X, Li H, Ke C, Tan Y, Cai C, Lai K, Chen $R$, Chan-Yeung $M$, Zhong $N$. Longitudinal profile of antibodies against SARS-coronavirus in SARS patients and their clinical significance. Respirology. 2006; 11:49-53.

https://doi.org/10.1111/j.1440-1843.2006.00783.x PMID:16423201

23. Zhang $W$, Du RH, Li B, Zheng $X S$, Yang $X L$, Hu B, Wang YY, Xiao GF, Yan B, Shi ZL, Zhou P. Molecular and serological investigation of 2019-nCoV infected patients: implication of multiple shedding routes. Emerg Microbes Infect. 2020; 9:386-89.

https://doi.org/10.1080/22221751.2020.1729071

PMID: $\underline{32065057}$

24. Lan L, Xu D, Ye G, Xia C, Wang S, Li Y, Xu H. Positive RTPCR test results in patients recovered from COVID-19. JAMA. 2020; 323:1502-03. https://doi.org/10.1001/jama.2020.2783 PMID:32105304

25. Corman VM, Landt O, Kaiser M, Molenkamp R, Meijer A, Chu DK, Bleicker T, Brünink S, Schneider J, Schmidt ML, Mulders DG, Haagmans BL, van der Veer B, et al. Detection of 2019 novel coronavirus (2019-nCoV) by real-time RT-PCR. Euro Surveill. 2020; 25:2000045.

https://doi.org/10.2807/1560-

7917.ES.2020.25.3.2000045

PMID:31992387

26. Ruan $Q$, Yang $K$, Wang $W$, Jiang $L$, Song J. Clinical predictors of mortality due to COVID-19 based on an analysis of data of 150 patients from Wuhan, China. Intensive Care Medicine. 2020; 46:1294-97. https://doi.org/10.1007/s00134-020-06028-z

27. Jung SM, Akhmetzhanov AR, Hayashi K, Linton NM, Yang Y, Yuan B, Kobayashi T, Kinoshita R, Nishiura H. Real-time estimation of the risk of death from novel coronavirus (COVID-19) infection: inference using exported cases. J Clin Med. 2020; 9:523.

https://doi.org/10.3390/icm9020523 PMID:32075152

28. Li G, De Clercq E. Therapeutic options for the 2019 novel coronavirus (2019-nCoV). Nat Rev Drug Discov. 2020; 19:149-50.

https://doi.org/10.1038/d41573-020-00016-0

PMID: $\underline{2127666}$
29. Shang L, Zhao J, Hu Y, Du R, Cao B. On the use of corticosteroids for 2019-nCoV pneumonia. Lancet. 2020; 395:683-84.

https://doi.org/10.1016/S0140-6736(20)30361-5 PMID: 32122468

30. Russell CD, Millar JE, Baillie JK. Clinical evidence does not support corticosteroid treatment for 2019-nCoV lung injury. Lancet. 2020; 395:473-75. https://doi.org/10.1016/S0140-6736(20)30317-2 PMID:32043983

31. Arabi YM, Murthy S, Webb S. COVID-19: a novel coronavirus and a novel challenge for critical care. Intensive Care Med. 2020; 46:833-36. https://doi.org/10.1007/s00134-020-05955-1 PMID: $\underline{32125458}$

32. Ñamendys-Silva SA. Respiratory support for patients with COVID-19 infection. Lancet Respir Med. 2020; 8:e18.

https://doi.org/10.1016/S2213-2600(20)30110-7 PMID:32145829

33. Wang $M$, Cao R, Zhang L, Yang $X$, Liu J, Xu M, Shi Z, Hu Z, Zhong W, Xiao G. Remdesivir and chloroquine effectively inhibit the recently emerged novel coronavirus (2019-nCoV) in vitro. Cell Res. 2020; 30:269-71.

https://doi.org/10.1038/s41422-020-0282-0 PMID:32020029

34. Holshue ML, DeBolt C, Lindquist S, Lofy KH, Wiesman J, Bruce H, Spitters C, Ericson K, Wilkerson S, Tural A, Diaz G, Cohn A, Fox L, et al, and Washington State 2019nCoV Case Investigation Team. First case of 2019 novel coronavirus in the United States. N Engl J Med. 2020; 382:929-36.

https://doi.org/10.1056/NEJMoa2001191 PMID: $\underline{32004427}$

35. Ranieri VM, Rubenfeld GD, Thompson BT, Ferguson ND, Caldwell E, Fan E, Camporota L, Slutsky AS, and ARDS Definition Task Force. Acute respiratory distress syndrome: the berlin definition. JAMA. 2012; 307:2526-33.

https://doi.org/10.1001/jama.2012.5669 PMID:22797452

36. Shankar-Hari M, Phillips GS, Levy ML, Seymour CW, Liu VX, Deutschman CS, Angus DC, Rubenfeld GD, Singer $M$, and Sepsis Definitions Task Force. Developing a new definition and assessing new clinical criteria for septic shock: for the third international consensus definitions for sepsis and septic shock (Sepsis-3). JAMA. 2016; 315:775-87. https://doi.org/10.1001/jama.2016.0289 PMID:26903336 